\title{
Type 1 Collagen X-link N-Telopeptides to Creatinine Ratio Measurement
}

National Cancer Institute

\section{Source}

National Cancer Institute. Type 1 Collagen X-link N-Telopeptides to Creatinine Ratio

Measurement. NCI Thesaurus. Code C147408.

The determination of the ratio of the type 1 collagen $\mathrm{X}$-link $\mathrm{N}$-telopeptides compared to creatinine present in a sample. The measurement may be expressed as a ratio or percentage. 